
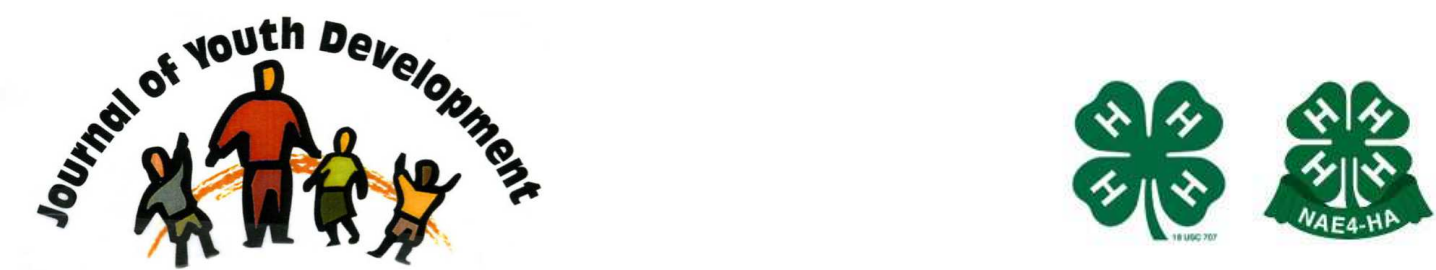

Bridging Research \& Practice

\title{
Perceived Effectiveness of Youth-Adult Partnerships on Enhancing Life Skill Development through 4-H
}

\author{
Jeff Sallee \\ Oklahoma State University \\ Stillwater, OK \\ jeff.sallee@okstate.edu \\ Charles Cox \\ Oklahoma State University \\ Stillwater, OK \\ charles.cox@okstate.edu
}




\title{
JOURNAL OF YOUTH DEVELOPMENT \\ bridging research and practice

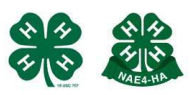

\section{Perceived Effectiveness of Youth-Adult Partnerships on Enhancing Life Skill Development through 4-H}

Jeff Sallee and Charles Cox Oklahoma State University

\begin{abstract}
The purpose of this study was to determine if youth and adult participants in the 4-H Environmental Impact program perceive youth-adult partnerships as an effective means to enhance the youths' development of life skills. The study further sought to discover the perceived obstacles that may keep youth and adults from participating in equal partnerships. The life skills of: Leadership, Cooperation, Service Learning, and Planning and organizing were enhanced through the youths' participation in the youth-adult partnership. Through this research there was evidence that many of the youth participants did perceive themselves as equal team members when participating in this youth-adult partnership. The research indicated the greatest perceived obstacle that kept youth from engaging was not much time after homework and other activities. It is recommended that all participants in newly formed youth-adult partnerships receive training on how to implement this type of program, and how to participate equally.
\end{abstract}

\section{Introduction}

Leadership development has been, and continues to be a major goal of the 4-H Youth Development program. As the world enters the 21st century, many youth programs, including 4-H, are focusing on the effectiveness of their leadership training (Seevers, 1995). A historical approach to teaching leadership to $4-\mathrm{H}$ youth has been through life skill development. Life skills have been defined as the abilities that are useful for living everyday life. They include thinking, doing and feeling skills. The overall purpose of the life skills approach to leadership training was the development of skills necessary to perform leadership functions in real life (Miller, 1976). 
The purpose of this study was to determine if youth and adult participants in the 4-H Environmental Impact program perceive youth-adult partnerships as an effective means to enhance the youths' development of life skills. The study further sought to discover if there were perceived obstacles that may keep youth and adults from participating in youth-adult partnerships.

\section{Objectives for this Study}

1. To determine if youth and adult team members perceive that youth developed the life skills of leadership, cooperation, contributions to group efforts, accepting differences, service learning, planning and organizing through participation in youth-adult partnerships.

2. To determine if youth perceive themselves as equal team members when serving in a partnership with adults.

3. To discover if there are perceived obstacles that may keep youth from engaging in youthadult partnerships.

4. To discover methods for improving newly developed youth-adult partnerships in order to develop life skills.

\section{Design and Procedures}

The research was an exploratory study to determine the perceptions of youth and adults involved in partnerships through Oklahoma 4-H Youth Development Environmental Impact programs. Specifically the study sought to determine how youth perceived the development of life skills through their involvement in the youth-adult partnership.

The design selected for this research was a mixed method approach. A mixed method design is a procedure for collecting, analyzing, and mixing both quantitative and qualitative data in a single study (Creswell, 2005). The research study consisted of a quantitative pre-survey and post-survey regarding the perceptions of the participants. The study also involved a qualitative assessment. The adult participants were asked to complete an open-ended report of their experiences relating to the project. The ultimate outcome of this approach was to determine the perceptions of the adult participants regarding youth-adult partnerships developing life skills. By assessing both quantitative and qualitative outcomes we can develop a complex picture of the social phenomena (Creswell, 2005). The mixed method design was the most appropriate means to collect the necessary data to analyze the participants' perceptions of developing life skills through youth-adult partnerships.

The internal consistency method provides a unique estimate of reliability of the survey instrument for the given test administration. The most popular internal consistency reliability estimate was given by Cronbach's alpha. According to Ary, Jacobs, and Razavieh (1972) most test makers and researchers are satisfied if they obtain a Cronbach's alpha indicator greater than .70. Subsequently, all questions on the survey which received a rating lower than .70, on this research, were not used in the findings of this study. 


\begin{tabular}{|c|c|}
\hline \multicolumn{2}{|c|}{ Cronbach's Alpha Score For Youth and Adult Survey Life Skill Questions } \\
\hline Life Skill & \begin{tabular}{|l} 
Alpha \\
Values
\end{tabular} \\
\hline \multicolumn{2}{|l|}{ Youth Survey Questions } \\
\hline $\begin{array}{l}\text { Leadership } \\
\text { Accepting Differences } \\
\text { Contributions to Group Efforts } \\
\text { Planning and Organizing } \\
\text { Service Learning } \\
\text { Cooperation }\end{array}$ & $\begin{array}{l}0.76 \\
0.74 \\
0.70 \\
0.82 \\
0.73 \\
0.95\end{array}$ \\
\hline \multicolumn{2}{|l|}{ Adult Survey Questions } \\
\hline $\begin{array}{l}\text { Leadership } \\
\text { Accepting Differences } \\
\text { Contributions to Group Efforts } \\
\text { Planning and Organizing } \\
\text { Service Learning } \\
\text { Cooperation }\end{array}$ & $\begin{array}{l}0.82 \\
0.73 \\
0.71 \\
0.78 \\
0.95 \\
0.73\end{array}$ \\
\hline
\end{tabular}

The survey results were compiled and analyzed to determine the change in the participants' perception of youth-adult partnerships after collaborating in a youth-adult partnership for one year. Descriptive statistics were used to determine the change in the participants' perceptions from the pre-survey to the post-survey. All results from individuals who completed a pre and post survey were compiled and evaluated as a population. These results were summarized for triangulation with the qualitative data.

All surveys were coded and participants' names were kept in strict confidence. Because this survey involved a youth audience, parental consent forms were required before the survey was administered. All forms and procedures were Internal Review Board approved; \#AG0544.

\section{Scope of the Study}

The population for this study was the youth and adults who were involved in the youth-adult teams participating in the Oklahoma 4-H Youth Development Environmental Impact team during 2005-2006. The population consisted of teams of youth and adult partners from 16 Oklahoma counties. Study respondents from the 16 locations self-selected to participate. A census was used for the study, therefore sampling was not required.

\section{Findings and Conclusions}

\section{Population of the Study}

The study was designed to involve the population of youth and adults who were participating in the Oklahoma 4-H Youth Development Environmental Impact team. This population included educators, volunteers and youth from sixteen locations. From this group, 36 youth and 9 adults self-selected to participate in the study by taking the pre-survey. There were additional educators involved who chose not to participate in the pre-surveys. Due to IRB guidelines, 
educator participation in this research was not mandatory and had no reflection on their job performance. However, after the program, several of these educators did chose to participate in the research by completing an Adult Participant Report. The number of participants in this study was small. However, if the total population of this project had chosen to participate and completed all the research instruments, pre and post, approximately 20 adults and 60 youth would have been involved. Twenty youth, who completed the pre-survey, did not complete the project or did not complete the post-survey. Following, is the number of participants whose data was analyzed in the findings; 16 youth completed the pre-post surveys, 8 adults completed the pre-post surveys, and 14 adults completed an Adult Participant Report.

There were 14 total adults who completed both the pre-survey and the post-survey, or the Adult Report. Fourteen adult participants completed the Adult Report while 8 completed both the pre-survey and post-survey. These adults were all involved with their county 4-H environmental youth-adult partnership for the first year of the project. There were 8 male and 6 female adult participants, the average age was 39.35, ranging from 25 to 53 years old. All of the participants were Caucasian. The adult participants had been involved in 4- $\mathrm{H}$ from 0 to 26 years with an average of 13.50 years. The majority of these adults (71.5\%) spent from $2-10$ hours each month doing community service.

\begin{tabular}{|c|c|c|c|c|c|}
\hline \multicolumn{6}{|c|}{ Demographics of Adult Participants at the end of the Pre-survey $(N=14)$} \\
\hline Survey Question & Frequency & Median & Minimum & Maximum & Percent \\
\hline \multicolumn{6}{|l|}{ Gender } \\
\hline $\begin{array}{l}\text { Male } \\
\text { Female }\end{array}$ & $\begin{array}{l}8 \\
6\end{array}$ & & & & $\begin{array}{l}57.1 \\
42.9\end{array}$ \\
\hline Age & & 41 & 25 & 53 & 100.00 \\
\hline \multicolumn{6}{|l|}{ Ethnicity } \\
\hline Caucasian & 14 & & & & 100.0 \\
\hline \multicolumn{6}{|c|}{ Highest Level of Formal Education } \\
\hline $\begin{array}{l}\text { Graduate degree } \\
\text { Four Year Degree } \\
\text { Some College }\end{array}$ & \begin{tabular}{|l|}
10 \\
3 \\
1 \\
\end{tabular} & & & & $\begin{array}{r}71.4 \\
21.4 \\
7.2\end{array}$ \\
\hline \multicolumn{6}{|l|}{ Role } \\
\hline $\begin{array}{l}\text { Paid Staff } \\
\text { Volunteer }\end{array}$ & $\begin{array}{l}13 \\
1 \\
\end{array}$ & & & & $\begin{array}{r}92.9 \\
7.1 \\
\end{array}$ \\
\hline Years Involved in $4-\mathrm{H}$ & & $11-15$ & 0 & 26 & \\
\hline \multicolumn{6}{|c|}{ Hours spent doing Community Service each Month } \\
\hline $\begin{array}{l}\text { More than } 20 \text { hours } \\
11-20 \text { hours } \\
2-10 \text { hours }\end{array}$ & \begin{tabular}{|l|}
3 \\
1 \\
10
\end{tabular} & & & & $\begin{array}{r}21.4 \\
7.1 \\
71.5\end{array}$ \\
\hline
\end{tabular}


There were 16 total youth who completed both the pre-survey and the post-survey. These youth were involved with their county 4-H environmental youth-adult partnership for the first year of the project. There were 11 boys and 5 girls, with the average age of 14.5 , ranging from 12 to 18 years old. Fourteen of the participants were Caucasian, one Hispanic and one indicated "other". The youth participants had been involved in 4-H from 2 to 8 years with an average of 5.19 years. The majority of these youth $(56.35 \%)$ spent from $2-10$ hours each month doing community service.

\begin{tabular}{|c|c|c|c|c|c|}
\hline \multicolumn{6}{|c|}{ Demographics of Youth Participants at Pre-survey $(\mathrm{N}=16)$} \\
\hline Survey Question & Frequency & Mean & Minimum & Maximum & Percent \\
\hline \multicolumn{6}{|l|}{ Gender } \\
\hline $\begin{array}{l}\text { Male } \\
\text { Female }\end{array}$ & $\begin{array}{l}11 \\
5\end{array}$ & & & & $\begin{array}{l}68.75 \\
31.25\end{array}$ \\
\hline Age & & 14.50 & 12 & 18 & \\
\hline \multicolumn{6}{|l|}{ Ethnicity } \\
\hline $\begin{array}{l}\text { Caucasian } \\
\text { Hispanic } \\
\text { Other }\end{array}$ & $\begin{array}{l}14 \\
1 \\
1\end{array}$ & & & & $\begin{array}{r}87.50 \\
6.25 \\
6.25\end{array}$ \\
\hline Years Involved in 4- $\mathrm{H}$ & & 5.19 & 2 & 8 & \\
\hline \multicolumn{6}{|c|}{ Hours spent doing Community Service each Month } \\
\hline $\begin{array}{l}\text { More than } 20 \text { hours } \\
11-20 \text { hours } \\
2-10 \text { hours } \\
\text { About } 1 \text { hour } \\
\text { None }\end{array}$ & $\begin{array}{l}1 \\
3 \\
9 \\
2 \\
1\end{array}$ & & & & $\begin{array}{r}6.25 \\
18.80 \\
56.25 \\
12.50 \\
6.25\end{array}$ \\
\hline
\end{tabular}

As a part of the pre-survey the participants were asked if they had prior experience working in a youth-adult partnership. For the youth, 68.8\% indicated they had "Some" previous experience working in a youth-adult partnership, while $62.5 \%$ of the adults indicated they had "A lot" of prior experience working in youth-adult partnerships.

Objective 1: To determine if youth and adult team members perceive that youth developed the life skills of leadership, cooperation, contributions to group efforts, accepting differences, service learning, planning and organizing through participation in youth-adult partnerships.

From the participating teams involved in the project, the research indicated that the teams of youth and adults which gave the youth the opportunity to partner and help decide the direction of their program were more successful than the teams that tried to force the team into a specific project area. Norman (2001) stated a youth-adult partnership is one in which adults 
work in full partnership with young people on issues facing youth and/or on programs, and policies affecting youth.

The responses from question 1 on the qualitative Adult Participant Report indicated the closer the adult works with the youth partners in the design and implementation of the program, the more interest the youth will show in the project.

\section{Life Skills}

According to the triangulation of the findings in the data sources, the life skills of Leadership, Cooperation, Service Learning, and Planning and Organizing were enhanced through the youths' participation in the youth-adult partnership. Individual life skills results follow:

\section{Life Skills - Leadership}

All 14 of the adult respondents indicated on the qualitative Adult Report that the life-skill of Leadership was developed through the youth-adult partnership. A respondent stated the youth developed the life skill of Leadership through, "communicating with the adults in a role of leadership, and they had to be responsible in their data collection."

\begin{tabular}{|c|c|c|}
\hline \multicolumn{3}{|c|}{$\begin{array}{l}\text { Life skill and Number of Adult Respondents who identified the Life skill as } \\
\text { developed through the Environmental Impact program Youth - Adult } \\
\text { Partnership }\end{array}$} \\
\hline Life Skill & $\begin{array}{l}\text { Number of Times } \\
\text { Identified }\end{array}$ & $\%$ of $N(N=14)$ \\
\hline Leadership & 14 & 100 \\
\hline Cooperation & 13 & 93 \\
\hline Service Learning & 12 & 86 \\
\hline Contributions to Group Efforts & 10 & 71 \\
\hline Planning Organizing & 9 & 64 \\
\hline Accepting Differences & 6 & 43 \\
\hline
\end{tabular}

The quantitative questions on the pre-survey and the post-survey resulted in a positive change in the means of the questions related to developing the life skill of Leadership. Both, the youth and adults reported over a $10 \%$ increase in the mean scores from the pre-survey to the postsurvey on two of the questions related to the life skill of Leadership. The most notable differences were the questions which indicated youth were given the chance to share their feelings about things that mattered to them, and the youth's thoughts, ideas and suggestions were listened to by the other team members. Therefore, there was a positive relationship between youth participating in a true youth-adult partnership and youth enhancing the life skill of Leadership.

\section{Life Skills - Cooperation}

The qualitative analysis illustrated that 13 of the 14 adult respondents reported Cooperation as a life skill developed through the environmental program. The participants stated that the, "Youth and adults learned to work closely together to complete tasks" while another respondent 
stated, "The children had to cooperate with myself, with each other and with the adults while collecting data together and making decisions on which wells to test."

The quantitative survey questions related to the life skill of Cooperation indicated a small percentage drop in the level of cooperation in the pre-survey and post-survey means; however the change was less than $4 \%$. The one exception to this drop in perception was the youth response to the question, "How often do adults ask you about your thoughts and opinions?" The change in the mean response to this question was a notable $15 \%$ increase in the perception of the youth in how the adults value the thoughts and opinions of the youth.

Therefore, there was a mixed relationship between the qualitative and the quantitative responses of the enhancement of the life skill of Cooperation. Even though the quantitative values indicated a negative change, the identifiers associated with the values remained as positive responses to the survey questions. The qualitative data did indicate an enhancement in the youths' development of the life skill of Cooperation.

\section{Life Skills - Contributions to Group Efforts}

The qualitative analysis of Contributions of group efforts illustrated that 10 respondents indicated on the Adult Report form that the youth partners developed this life skill. A respondent stated this was their lowest scorer of the life skills while another respondent stated the partners developed great working relationships with each other. On the quantitative surveys, all the adult respondents indicated a positive change. The survey question, "How often do youth have specific assignments on the team" received mixed responses from the youth and the adults. The youth indicated a negative percent change in the pre-survey and post-survey means while the adults reported a positive change. The question, "How often are youth able to attend the activities planned by the team" received the same mixed response. Both the youth and adults agreed that the other youth team members were positive and responsive to the needs and questions of the other youth. These results indicate that the youth were willing to contribute to group efforts and develop this skill as long as they were able to participate with the team.

The results of the life skill of Contributions to group efforts were questionable as to whether this life skill was enhanced through the participation in a youth-adult partnership.

\section{Life Skills - Accepting Differences}

Only five of the 14 respondents identified this life skill as one developed through the program. An adult respondent stated, "I don't think this was an issue that was dealt with in the program." This may indicate the youth could learn this skill under different circumstances. On the quantitative Adult Participant Reports there was very little change in the mean scores. The findings for the life skill of Accepting Differences were inconclusive due to the lack of the identification of this life skill on the Adult Reports and the absences of change in the mean scores on the quantitative survey responses.

\section{Life Skills - Service Learning}

This life skill was reported by 12 of the 14 adult respondents on the Adult Report as a skill developed through the project. A common theme emerged through the qualitative data that the youth learned the importance and value of working with clientele throughout the community. 
The quantitative data questions corresponding to Service Learning reported almost a $9 \%$ increase in the youth response to "learn new skills," which correlate with over a $6 \%$ increase in the adult values. When asked if the youth "feel a sense of personal fulfillment in working to improve their community?" the adults reported over a $9 \%$ increase and the youth a $6 \%$ from the pre-survey to the post-survey. Therefore this data indicates an enhancement in the youths' development of the life skill of Service Learning.

\section{Life Skills - Planning and Organizing}

Nine of the 14 respondents identified this life skill on the qualitative Adult Report. The participants' responses emerged into a consistent theme that the youth learned to develop a plan and a timeline to accomplish their tasks.

On the pre-survey and the post-survey the respondents were asked to base their answers on 'how worried' they were these activities might interfere with: "their school schedule and activities," "their family time," and "their personal free time."

At the conclusion of this research youth indicated a $24.56 \%$ in their concern that the project would interfere with their school schedule and activities. The youth also indicated over a $16 \%$ increase in their concern with the environmental project interfering with their family life.

The adult respondents had lower values on the corresponding questions. The adults indicated a $12.85 \%$ increase in how worried the youth were the project would interfere with the youths' personal free time.

Therefore the results indicated the youth participants enhanced their life skill of Planning and Organizing. The results indicated the youth became more concerned about their schedules from the beginning to the end of the project. This finding might be interpreted the youth realized to what extent their time was limited. Through the qualitative Adult Reports the adults stated the youth increased their skills in Planning and Organizing.

Objective 2: To determine if youth perceive themselves as equal team members when serving in a partnership of youth and adults.

The responses by the youth to quantitative questions regarding their role on the team indicate that the youth felt an equal partnership with the adults. A notable change from an adult-led collaboration to a youth-adult partnership was evident by the over 30\% increase in the response to the question regarding receiving coaching from other youth on the team. The youth expected to receive coaching from the adults, it would appear that coaching from each other may have been a new concept. The adult responses to these same questions fell in the "sometimes" or "often" categories. This was an indicator that the adults were open to the youth choosing and changing their role on the team, and the youth being given more responsibility, or coaching each other and serving in a leadership role.

The adult participants were asked to, "Describe the relationship between the youth and adult partner(s) and your team." The general responses indicated an equal partnership between the youth and adults. One respondent stated, "The youth and adults work to have an equal relationship. At first the youth wanted the adults to take the lead but once we started an equal 
relationship formed quickly." This response was the most representative of teams exhibiting the qualities of youth-adult partnerships.

The adult respondents also suggested through the qualitative data the adults provided guidance and teaching to the team by drawing on their past experiences. This corresponds with Jones and Perkins (2000) thought that without adult guidance youth led projects may decline into negative and undesirable behaviors. However, it must be noted that the data also indicated that $100 \%$ of the teams did not function in this manner. There were 14 different teams in this study; they all seemed to operate somewhat differently.

Objective 3: To discover perceived obstacles that may keep youth from engaging in youth-adult partnerships.

Youth respondents identified two obstacles through the quantitative data that keep youth from fully participating in youth-adult partnerships: not much time after homework and other activities, and the meetings were not at a good time. These obstacles were selected by $50 \%$ of the youth participants. The two most identified obstacles (that may keep youth from participating in a youth-adult partnership) by the adult participants were: not much time after homework and other activities, and transportation to meetings. These two obstacles were selected by $87.5 \%$ of the adult respondents. Fifty percent of the adults reported that youth would rather be with their friends. Although it was notable that only $12.5 \%$ of the youth indicated they would rather be with their friends. 


\begin{tabular}{|c|c|}
\hline \multicolumn{2}{|c|}{$\begin{array}{l}\text { Perceived Reasons Youth Do Not Participate in Youth-Adult } \\
\text { Partnerships }\end{array}$} \\
\hline Youth $(\mathrm{N}=16)$ & $\%$ Identified \\
\hline \multicolumn{2}{|l|}{$\begin{array}{l}\text { What keeps you from participating } 100 \% \text { with the } \\
\text { project team? (Check all that apply) }\end{array}$} \\
\hline $\begin{array}{l}\text { - Not much time after homework and other } \\
\text { activities }\end{array}$ & 68.8 \\
\hline - Adults don't respect youth on the committee & 0 \\
\hline - Rather be with friends & 12.5 \\
\hline - Transportation to meetings & 12.5 \\
\hline - Not so interesting & 12.5 \\
\hline - Parents don't help youth get to the meeting & 12.5 \\
\hline - Meeting not at a good time & 50.0 \\
\hline Adults $(\mathrm{N}=8)$ & $\%$ Identified \\
\hline \multicolumn{2}{|l|}{$\begin{array}{l}\text { What keeps youth from participating } 100 \% \text { with the } \\
\text { project team? (Check all that apply) }\end{array}$} \\
\hline $\begin{array}{l}\text { Not much time after homework and other } \\
\text { activities }\end{array}$ & 87.5 \\
\hline - Adults don't respect youth on the committee & 12.5 \\
\hline - Rather be with friends & 50.0 \\
\hline - Transportation to meetings & 87.5 \\
\hline - $\quad$ Not so interesting & 37.5 \\
\hline - Parents don't help youth get to the meeting & 62.5 \\
\hline - Meeting not at a good time & 25.0 \\
\hline - Other & 12.5 \\
\hline
\end{tabular}

Two respondents identified time as a constraint that limited the project. Time was identified by the Innovation Center (2003) as a disadvantage of implementing youth-adult partnerships. It takes more time for a youth leader to partner with youth than it does to make a decision and implement that decision.

An additional identified discouragement to the youth-adult partnership was that the youth either lost interest, or did not show up at the meetings or work days. As one adult described, "When the project was presented, all team members were supportive of the efforts; however, time, and travel constraints limited the success of the project."

Many of these obstacles, such as time, transportation and interest, could be improved by including youth in the planning process, especially when scheduling meeting times and designing the project.

Objective 4: To discover methods for improving newly developed youth-adult partnerships in order to develop life skills.

Four themes emerged from the analysis of the data related to this objective;

1. no changes should be made in the program, 
2. the project needed to be more interesting for all the participants,

3. the project needed more participation in the decision making process, and

4. the teams should work more as a youth adult partnership.

In analyzing the four themes identified as methods to improve youth- adult partnerships, it would appear three of these themes involve a lack of youth involvement in the partnership. If youth were more engaged in the project design and the decision-making process, the teams might work as a true youth-adult partnership. More youth involvement in this project may have resolved the issues of: needed to be more interesting, needed more participation, and the teams should work more as a youth adult partnership. Increasing youth involvement could greatly improve the shortcomings in the environmental project, and the corresponding youthadult partnership.

The youth-adult partnership does not exist when adults discount youth input (Camino, 2000). The following two statements from participants illustrate this point, "Making sure that all adults allowed youth to have an equal part of all decisions," and "Stressing the need for these partnerships to be used more so that the youth become more confident in speaking out and working in the youth-adult partnership." Further development of participants understanding and implementation of a true youth-adult partnership may be the most effective method for improving newly developed partnerships.

\section{Recommendations}

The findings of this research support the recommendations for each stated research objective.

Objective 1: To determine if youth and adult team members perceive that youth developed the life skills of leadership, cooperation, contributions to group efforts, accepting differences, service learning, planning and organizing through participation in youth-adult partnerships.

According to the triangulation of the findings in the data sources, the life skills of Leadership, Cooperation, Service Learning, and Planning and Organizing were enhanced through the youths' participation in the youth-adult partnership. The other measured life skills of Contributions to Group Efforts and Accepting Differences were not clearly enhanced through this program effort.

Therefore it is recommended that before beginning 4-H programming utilizing youth-adult partnerships as a youth development tool, specific life skills should be targeted for enhancement. Once these skills are targeted the participants in the program should receive programmatic training through youth-adult partnership workshops to help them develop these specific skills within the youth participants. The participants should understand that the skills are developed through working in a youth-adult partnership, not just participating in a partnership.

Objective 2: To determine if youth perceive themselves as equal team members when serving in a partnership of youth and adults

Through this research there was evidence that many of the youth participants did perceive themselves as equal team members when participating in this youth-adult partnership. 
However, other youth may not have perceived themselves as equal partners and dropped out of the program or they may have just lost interest in the project or 4-H.

It is recommended that before initiating youth-adult partnership programming all the adults involved understand the concept of a youth-adult partnership and demonstrate a true appreciation for the youth partners and their opinions. Once the adults involved reach this understanding then the youth may feel appreciated and view themselves as equal team members.

Objective 3: To discover perceived obstacles that may keep youth from engaging in youth-adult partnerships

The research data generated by this study indicated the greatest perceived obstacle that kept youth from engaging was "not much time after homework and other activities." It could also be concluded that the "meeting not being at a good time" may be the cause of the transportation obstacle.

It is recommended that the youth-adult partnership team schedule meetings at a time that was convenient to all participants. In order to overcome these identified obstacles, the youth must be involved in setting the meeting schedule.

Objective 4: To discover methods for improving newly developed youth-adult partnerships in order to develop life skills

The data indicated the project needed to be more interesting, needed more participation, needed to work more as a youth-adult partnership, or didn't need a change. By incorporating more youth involvement in the project design and decision-making process, this project may have resolved these two issues.

It is recommended that all participants in newly formed youth-adult partnerships receive training on how to implement and participate equally in this type of programming.

Staff development and 4-H Leader training should be conducted to ensure greater participation by youth in planning, implementing, and evaluating program activities. Adults may need to be taught to share authority roles, and respect youth for the contributions they can make in the leadership process (Seevers, \& Dormody, 1995, p.12).

Training can help the youth and adult participants improve their participation, working relationships, and partnership in this type of effort.

\section{Implications of the study}

Because this research was conducted as an exploratory study to determine the perceptions of youth and adults involved in partnerships in a specific program at a specific place and time the findings are only applied to that population. However, the implications of this study could affect how the Oklahoma 4-H program uses the youth development tool of youth-adult partnerships in other programs in the future. Research has supported the notion that youth-adult partnerships 
do have the ability to enhance the life skill development in 4- $\mathrm{H}$ youth and as such should be considered by youth development professionals.

As 4-H programs implement this type of programming, training should be provided to all the partners (youth and adult) involved prior to the development of the youth-adult relationship. Youth should understand they have an equal voice in the program design and implementation. Adults should understand the special needs of youth, such as meeting schedules and transportation to events. Adults should also understand it is imperative they place a high value on the youths' opinion and participation in the project development. Both, the youth and adults should understand that there is a balance in a youth-adult partnership where the youth and the adults have an equal voice. This point of balanced leadership and commitment is the ideal context for the development of life skills within the youth partners. According to the research and the literature, youth-adult partnership can enhance youth development programs, but to be effective they must be conducted properly. Simply supporting the concept without understanding it and fully embracing it doesn't seem to be adequate.

\section{References}

Ary, D., Jacobs, L.C., \& Razavieh, A. (1972). Introduction to research in education. New York: Holt, Rinehart and Winston, Inc.

Camino, L.A. (2000). Entering new territory in community work and research. Applied Developmental Science, 4, 11-20.

Creswell, J.W. (2005). Educational research: Planning, conducting, and evaluating quantitative and qualitative research (2nd ed.). Columbus, $\mathrm{OH}$ : Pearson.

Innovation Center for Community and Youth Development and National 4-H Council. (2003). At the table: Youth in decision-making. Retrieved November 8, 2005, from:

http://www.atthetable.org/images/Details/03130216083639 YouthinDecisionMakingBrochureRe vised9-01.pdf

Jones, K.R., \& Perkins, D.F. (2005). Determining the quality of youth-adult relationships within community-based youth programs. Journal of Extension, 43(5).

Miller, R.A. (1976). Leader/agents guide: Leadership life skills. Stillwater: Oklahoma State University.

Norman, J. (2001). Building effective youth-adult partnerships [Electronic Version]. Transitions, 14. Retrieved Novmeber 5, 2005 from:

http://www.advocatesforyouth.org/publications/transitions/transitions1401 7.htm.

Seevers, B.S., \& Dormody, T.J. (1995). Leadership life skills development: Perceptions of senior 4-H youth. Journal of Extension, 33(4).

(C) Copyright of Journal of Youth Development Bridging Research and Practice. Content may not be copied or emailed to multiple sites or posted to a listserv without copyright holder's express written permission. Contact Editor at: patricia.dawson@oregonstate.edu for details. However, users may print, download or email articles for individual use.

ISSN 2325-4009 (Print); ISSN 2325-4017 (Online) 